\title{
REPORTS OF NOTE
}

\section{Reshaping the Graduate Education of Scientists and Engineers 1995}

U.S. graduate schools need to institute new approaches to training because "changes in science and in the needs of employers are placing new stresses on the system," according to a new study by the National Academy of Sciences.

Reshaping the Graduate Education of Scientists and Engineers recommends: that graduate programs need to be more flexible and provide more options for students; that students should receive better career information and guidance; that a national database with information on employment options should be established; that the time to obtain a degree should be shortened; and that education/training grants be awarded competitively to institutions and departments that propose to improve the versatility of their students by offering them more experience while they are in a structured program.

National Academy Press

2101 Constitution Avenue, NW

Washington, DC 20418

\section{Medicine and the Media: A Changing Relationship} 1994

Medical historian Lester King was once quoted as having said, "Doctors want to tell the public what it needs to know, while the media wish to tell the public what it wants to hear." This statement is at the heart of a report from a recent conference on the somewhat tenuous relationship between medicine and the media. The Robert R. McCormick Tribune Foundation organized the two-day conference.

It was recommended that full disclosure of "possible conflicts for all concerned with research, including reviewers and journal editors" become routine. The "suspicion of the news media and fear of power of medical and scientific journals" can be combatted, according to some participants, by eliminating the politics that prohibit re-

searchers from discussing their work with the media before it is published. Journalists should avoid making more out of a scientific discovery than is necessary.

Both parties agreed that the best approach in handling the many pressures from outside sources is to stick with their instincts about maintaining professional and personal integrity in reporting about current medical and scientific research. Communication between the medical community and the media is vital and will ensure that the news coverage is accurate and understandable.

\section{Robert R. McCormick Tribune Foundation \\ 435 North Michigan Avenue, Suite 770 Chicago, Illinois 60611}

\section{The Best Intentions: Unintended Pregnancy and the Well-Being of Children and Families 1995}

Almost 60 percent of all pregnancies in the United States are unintended, mistimed or unwanted entirely according to a new Institute of Medicine report, The Best Intentions: Unintended Pregnancy and the Well-Being of Children and Families. It recommends a multifaceted, longterm public-private campaign to reduce the number of unwanted pregnancies by focusing on planning rather than avoiding pregnancy.

The campaign to reduce unintended pregnancy includes basic goals: to improve knowledge of contraception, unintended pregnancy and reproductive health; to increase access to contraception; and to address the major roles that feelings, attitudes and motivation play in using contraception. Stimulating research to develop new contraceptive methods for women and men, answering questions about how to organize contraceptive services, and understanding the determinants and antecedents of unintended pregnancy will help achieve these goals.

National Academy Press

2101 Constitution Avenue, NW

Washington, DC 20418

\section{Human Tissue: Ethical and Legal Issues 1995}

Human tissue, including blood, should never be bought or sold according to a report released in April from a leading bioethics panel in Britain. The Nuffield Council on Bioethics says that tissue is not a commodity, and its removal and collection should not be organized along commercial lines.

Instead the report, Human Tissue: Ethical and Legal Issues, recommends that the gift relationship should be protected. "The altruistic motivation of patients, donors and relatives should be respected and encouraged rather than eroded," in hope that this will make more come forward. "Payment to donors may cover only their reasonable expenses and inconvenience incurred and should not act as an inducement."

The independent committee of legal, ethical and medical experts is also against inducements that are in kind, not money. Examples include the offer of lifetime medical treatment in exchange for kidney donation or free fertility treatment in return for the donation of ova.

The report also discusses the claims of people from whom tissue is removed. The most celebrated case is that of John Moore, a leukaemia patient who sued the University of California, Los Angeles. Moore attempted to claim an interest to products derived from his spleen, on the basis that he had property rights to the tissue. Moore lost.

In the UK, the law does not recognize any right of property in a body. However, this view is derived from 19th century cases of grave robbing and has not been tested in any case where a tissue sample turned out to be a valuable source of biotechnology products. To remove this legal uncertainty, the report recommends that, in giving consent to treatment, patients should also understand that they will be regarded as having abandoned any tissue removed in the course of the treatment.

Nuffield Council on Bioethics 28 Bedford Square London WC1 3EG, UK

Compiled by Jennifer K. Snow and Nuala Moran 